\title{
The stock performance of America's 100 best corporate citizens
}

\section{Article}

Accepted Version

Brammer, S., Brooks, C. and Pavelin, S. (2009) The stock performance of America's 100 best corporate citizens. The Quarterly Review of Economics and Finance, 49 (3). pp. 10651080. ISSN 1062-9769 doi:

https://doi.org/10.1016/j.qref.2009.04.001 Available at https://centaur.reading.ac.uk/18676/

It is advisable to refer to the publisher's version if you intend to cite from the work. See Guidance on citing.

Published version at: http://dx.doi.org/10.1016/j.qref.2009.04.001

To link to this article DOI: http://dx.doi.org/10.1016/j.qref.2009.04.001

Publisher: Elsevier

All outputs in CentAUR are protected by Intellectual Property Rights law, including copyright law. Copyright and IPR is retained by the creators or other copyright holders. Terms and conditions for use of this material are defined in the End User Agreement.

\section{www.reading.ac.uk/centaur}

\section{CentAUR}

Central Archive at the University of Reading 
Reading's research outputs online 
NOTICE: this is the author's version of a work that was accepted for publication in the Quarterly Review of Economics and Finance. Changes resulting from the publishing process, such as peer review, editing, corrections, structural formatting, and other quality control mechanisms may not be reflected in this document. Changes may have been made to this work since it was submitted for publication. A definitive version was subsequently published in the Quarterly Review of Economics and Finance, 49 (2009), DOI: 10.1016/j.qref.2009.04.001 


\title{
The Stock Performance of America's 100 Best Corporate Citizens
}

\author{
Stephen Brammer \\ Chris Brooks* \\ Stephen Pavelin \\ University of Bath \\ University of Reading \\ University of Reading
}

March 2009

Keywords: corporate citizenship, Business Ethics "100 Best Corporate Citizens", corporate social responsibility, stock returns, trading rule performance.

JEL Classifications: G10, G14, M14, M20

Acknowledgment: The authors are grateful to an anonymous referee whose comments helped to focus and improve the paper, and to Barbara Docherty for copy-editing the manuscript. The usual disclaimer applies.

* Corresponding author: ICMA Centre, University of Reading, PO Box 242, Whiteknights, Reading RG6 6BA, UK; t: (+44) 118931 7809; f: (+44) 11893147 41; e-mail: C.Brooks@icmacentre.rdg.ac.uk . 


\title{
The Stock Performance of America's 100 Best Corporate Citizens
}

\begin{abstract}
We consider the stock performance of America's 100 Best Corporate Citizens following the annual survey by Business Ethics. We examine both possible short-term announcement effects around the time of the survey's publication, and whether longer-term returns are higher for firms that are listed as good citizens. We find some evidence of a positive market reaction to a firm's presence in the Top 100 firms that are made public, and that holders of the stock of such firms earn small abnormal returns during an announcement window. Over the year following the announcement, companies in the Top 100 yield negative abnormal returns of around 3\%. However, such companies tend to be large and with stocks exhibiting a growth style, which existing studies suggest will tend to perform poorly. Once we allow for these firm characteristics, the poor performance of the highly rated firms declines. We also find companies that are newly listed as good citizens and companies in the Top 100 but outside the S\&P 500 can provide considerable positive abnormal returns to investors, even after allowing for their market capitalization, price-to-book ratios, and sectoral classification.
\end{abstract}

\section{Introduction}

In spite of very mixed research findings concerning the financial performance of socially responsible investment (SRI) funds (Hamilton et al., 1993), recent evidence indicates that such funds now account for over $12 \%$ of all assets under management in the US. Although smaller, the proportion of assets managed according to ethical principles is rising rapidly in the UK, continental Europe, and Australia (Schroder, 2004; Scholtens, 2005). Research also indicates that investors believe good companies to be good investments for their owners as well (McLachlan and Gardner, 2004).

Orthodox financial theory, built on the premise of efficient financial markets, suggests that in the long run portfolios that are not optimally diversified will achieve lower returns for a given level of risk than the market portfolio. Since SRI funds are subsets of the market portfolio that exclude some assets with socially undesirable characteristics, theory would suggest that they should incur a performance penalty. At the level of individual equities, a firm's current or past social performance should not provide any useful information concerning its future stock price performance but funds selecting only from among ethical stocks should underperform. After allowing for factors such as the industry in which the firm operates, its risk, and its size, firms with good social performance should not earn abnormal returns. Unexpected changes in social performance may lead to stock price movements, but these should be unpredictable, oneoff shifts. ${ }^{1}$

An alternative view, first proposed by Moskowitz (1972), is that SRI funds could outperform conventional funds because they make use of important information concerning the social performance of companies that is not fully and instantaneously reflected in security prices. A firm's social performance could be viewed as a proxy for a range of organizational characteristics, including good relations with stakeholders

\footnotetext{
${ }^{1}$ According to finance theory, only unexpected changes in a firm's activities and characteristics should lead to a change in its market value; any planned changes in activities should already be accounted for in the current share price. Thus, only unanticipated modifications to a firm's level of social performance - either good or bad - should yield a market reaction. Examples of good changes could include an announcement of improved conditions for workers or a new commitment to the use of only renewable energy. Examples of bad changes could be an oil spill, an industrial accident, or an unexpected withdrawal of a commitment to equal opportunities.
} 
and a managerial capacity for innovation. The significance of these characteristics may be underappreciated by markets (Waddock and Graves, 1999) so that the current and past social performance of firms could provide a valuable guide to future financial performance. ${ }^{2}$

The potential influence on stock market valuations of firms' social performance has been supported by much anecdotal evidence, the rise of the socially responsible investment movement, and the findings of some studies of stock selection among institutional investors. For example, Graves and Waddock (1994) and Cox et al. (2004) find evidence, for the US and the UK, respectively, of a positive relationship between corporate social performance and the proportion of a firm's stock that is owned by institutional investors. This suggests a preference for firms that exhibit strong social performance and that poor corporate social performance may lead to firms being screened-out of these large and influential portfolios.

A third possibility is that firms with good social performance earn negative abnormal returns since the euphoria surrounding them has caused investors to pay too much. Eventually, the firm's operating performance will not be able to deliver the promise, causing a reversal in its share price. There is widespread international evidence of over-reactions in stock markets, whereby firms whose stock prices have appreciated the most have a tendency to underperform subsequently (see, for example, DeBondt and Thaler, 1985, 1987; Chen and DeBondt, 2004). Such over-reaction and subsequent reversals are hard to explain using rational pricing approaches, and have encouraged a renewed interest in behavioral models.

In this paper, we conduct an analysis of the relationship between firm social and financial performance using data from Business Ethics annual "100 Best Corporate Citizens" survey. We enhance the existing literature on socially responsible investment and the interaction between social and financial performance in several ways. First, much of the existing literature captures the degree to which an investment fund or company is socially responsive in fairly crude ways. For example, several early studies drew a distinction between firms active and non-active in South Africa (Rudd, 1981; Grossman and Sharpe, 1986). More recent studies have tended to define firms as socially responsible according to their performance in a particular area of social responsibility (Jones and Murrell, 2001; Filbeck and Preece, 2003a, 2003b; Derwall et al., 2004), or investment funds as socially responsible by a narrow range of characteristics, usually the exclusion of tobacco and/or arms companies (Hamilton et al., 1993), or on the basis of a fund's self-classification as an SRI fund or otherwise (Schroder, 2004). By contrast, the data that we use to capture the degree to which corporations are socially responsible have several advantages over those

\footnotetext{
${ }^{2}$ The Universities Superannuation Scheme (USS) is the third largest pension scheme in the UK, and is one of a growing number of such funds that have a social responsibility mandate. Their "Statement of Investment Principles," under the heading "Responsible Investment," states, "As an institutional investor that takes seriously its fiduciary obligations to its members, the trustee company aims to be an active and responsible long-term shareholder of companies and markets in which it invests. The trustee company pursues this policy in order to protect and enhance the value of the fund's investments by encouraging responsible corporate behavior," (p. 5). This phraseology clearly indicates that USS believes that socially irresponsible firms are more likely to generate lower stock returns in the long run.
} 
employed in earlier research. In contrast to earlier research, the Business Ethics data we use involve a multidimensional measure of each firm's social performance. This measure encompasses the interests of all the major stakeholders interacting with the firm. The indicators cover a number of aspects of a firm's social orientation, including the quality of its community, employee and customer relations, and performance regarding the natural environment and employee diversity. This data provide a broad and reliable picture of the social performance of the firms we study.

Second, we attempt to overcome several potentially serious methodological concerns that may have plagued existing studies in this area. We allow for the impact of firm characteristics (e.g. sector, size, market-to-book ratio) and we also include in our database all companies outside the Top 100 best citizens that were S\&P 1500 members at any time during our sample period as a control sample. ${ }^{3}$ The S\&P 1500 index is a "super composite" that incorporates all S\&P 500 large-cap, S\&P 400 mid-cap, and S\&P 600 small-cap stocks, and thus should constitute a useful set of firms against which to benchmark those in the Business Ethics Top 100. We examine the influence of firm size and style in various ways to determine the robustness of our findings. We also endeavor to deal with a number of statistical issues relating to the measurement of the significance of both event time and longer-term abnormal returns by employing appropriate reference portfolios and skewness-adjusted test statistics with critical values derived from bootstrapping.

\section{Corporate Citizenship and Stock Returns}

Corporate citizenship is a concept that has evolved from a body of work that sought to define the wider roles of businesses within society and it is related to ideas about corporate social responsibility (CSR) (Carroll, 1999; Matten and Crane, 2005). In this view, a good corporate citizen is a company that "meets the economic, legal, ethical and discretionary responsibilities imposed on them by their stakeholders" (Maignan and Ferrell, 2000: 284). Our study employs a firm-level measure that seeks to quantify the concept of corporate citizenship, and in doing so attempts to encompass all key aspects of a firm's interaction with the wider society. This results in a composite that incorporates accounting measures of the scale of a firm's economic activity and its financial performance, as well as measures derived from objective criteria of the more familiar aspects of social performance, such as community relations, environmental performance, and so on.

The influence on investor behavior of non-financial corporate information is the subject of a growing body of academic literature. For example, a number of studies have investigated the influence of corporate reputation indices (e.g. Fortune magazine's "America's Most Admired Companies") on share price performance. Notable studies find that the stocks of the most admired firms, as identified by the Fortune survey, outperform those of the least admired (Filbeck et al., 1997; Antunovich et al., 2000) and/or market

\footnotetext{
${ }^{3}$ We are careful to include the stocks of companies that died during our sample period. At the month when the company disappears from the database, we assign a return of 0 and assume that the stock was sold at the last prevailing share price with the proceeds reinvested equally across all other stocks in the portfolio.
} 
indices (Filbeck et al., 1997; Vergin and Qoronfleh, 1998). Chung et al. (2003), on the other hand, find little evidence that highly rated firms outperform those that are less admired on a risk-adjusted basis.

This study is related in various respects to a diverse literature that seeks to analyze the links between a company's share performance and the extent to which it acts in a socially responsible manner. Such studies differ greatly in the manner in which CSR is measured. One may employ a general measure of CSR or focus upon one aspect of social performance, e.g. community-related, such as charitable giving (Brammer and Millington, 2005), environmental, such as pollution control (Derwall et al., 2004), or employee-related, such as maternity and paternity policies (Filbeck and Preece, 2003a). The authors of the latter study employ data from the 1998 US survey conducted by Fortune magazine in producing its list of "100 Best Companies to Work for in America." Based upon the responses of employees as well as the independent assessment of the magazine, this award considers work/family balance, remuneration, and a range of other issues. Both immediate price reactions on announcement of the contents of the list and long-term buy-and-hold abnormal returns (BHAR) are examined. The average market-adjusted abnormal return on the event day is a highly significant $4 \%$, while the average abnormal return for the following year is $11.8 \%$. The authors conclude that "the stock market does value corporate concern for workers" and that their findings imply that "the market perceives that the positive benefits accruing to [the Top 100] firms outweigh the costs of providing outstanding benefits [to their employees]."

However, the same authors present somewhat contrary findings in a similar study of the "Most FamilyFriendly Companies" survey published by Working Mothers magazine. There, they report a negative stock market response associated with the announcement date (Filbeck and Preece, 2003a). Despite the fact that Jones and Murrell (2001) report statistically significant positive abnormal returns associated with firsttime inclusion in the Working Mothers list, the Fortune survey appears to have a superior impact on stock returns, which may be due its wider readership.

The majority of studies on the impact of CSR on stock market valuations of firms have focused upon the returns associated with socially responsible funds rather than individual stocks, and the findings have been mixed. For example, Hamilton et al. (1993) study the investment performance of a sample of SRI mutual funds relative to that of a sample of conventional funds. They find that the SRI funds do not earn statistically significant excess returns relative to conventional funds, leading them to conclude that "the market does not price socially responsible characteristics." These findings are echoed in those of another more recent study that assesses the performance of SRI funds relative to their conventional counterparts. Statman (2000) finds a tendency for SRI funds to perform better, but not statistically significantly better, than conventional funds over the period 1990-1998. He concludes that "pooling investing power for something other than making money [i.e. to achieve social "good"] is no worse at making money than pooling it for money alone" (p. 38). However, the use of such data renders it difficult to determine whether fund performance is a result of the performance of socially responsible versus socially 
irresponsible stocks or a result of the abilities of fund managers. These abilities may systematically differ between SRI and conventional funds since it may be that the latter, typically larger, type of fund tends to be better managed.

Allen and Kask (1997) overcome this limitation by identifying the CSR characteristics of individual companies and by using that information in conjunction with the performance of individual stocks. They employ firm-level social performance data courtesy of Kinder, Lydenberg, Domini and Company (KLD) to identify firms that exhibit strong social performance. Specifically, they categorize a firm as "socially responsible" if it is deemed by KLD to have strengths and no weaknesses in the each aspect of CSR reported by that source at that time. The rating encompasses issues relating to communities, the environment, women, and minority groups. Despite finding strong social performance to be associated with a positive effect on profitability, they find a negative corresponding effect on stock market valuations. Statman (2006) finds the relative performance of socially responsible versus conventional stocks to be time varying. Socially responsible stocks outperformed the S\&P 500 during the late 1990s, but underperformed from 2000 onwards. Brammer et al. (2006) provide comparative evidence in the UK context. These contradictory results are symptomatic of the lack of any clear lessons from the extant literature on the link between CSR and stock returns.

\section{Data}

\subsection{The Business Ethics "100 Best Corporate Citizens" Survey}

The Corporate Citizenship scores used to identify and rank the Top 100 companies in each year are constructed (by Sandra Waddock, Samuel Graves, and Marjorie Kelly) from a number of components, reflecting a desire to "identify firms that excel at serving a variety of stakeholders well." A list of the "100 Best Corporate Citizens" is published annually, along with the scores and ranking of each firm, within the pages of Business Ethics in March (2000, 2001, 2003), April (2002), or May (2004). In addition to being published in Business Ethics, the annual citizenship rankings attract widespread news coverage. The media search engine Factiva suggests that the "100 Best Corporate Citizens" attract significant contemporaneous media interest within the US in such publications as the New York Times and Wall Street Journal, in addition to some international coverage. In an effort to acknowledge the multiplicity of stakeholders potentially affected by corporate actions and performance, scores are now complied on seven stakeholder groups: stockholders, community, minorities and women, employees, environment, non-US stakeholders, and customers. ${ }^{5}$ The scores draw on both financial information and measures of corporate social performance. The financial components used vary across the period: from 2000-2003, Revenue, Net income, ${ }^{6}$ and Total return to shareholders (stock price increases + dividends) are included; in 2004, only Total return to shareholders is included. Revenue and Net income figures are drawn with a two-year lag. For example, the 2000 scores derive from the Revenue and Net income recorded in 1998. Impacts on

\footnotetext{
${ }^{4}$ Business Ethics www.business-ethics.com/100best.htm.

${ }^{5}$ The environment, minorities, and non-US stakeholder categories were only incorporated from 2001.

${ }^{6}$ Any firms making losses were dropped.
} 
shareholders are measured by the returns over a three-year period; 1996-1998 for the 2000 scores; 1997-1999 for the 2001 scores; 1998-2000 for the 2002 scores. In subsequent years, the returns over a single year (again with a two-year lag) are employed.

The social performance components are derived from the Socrates database compiled by KLD, which covers a large sample of companies (rising from 650 to 1000 across the period) defining the set from which the Business Ethics Top 100 are drawn. In all years (2000-2004), the social performance components include Community relations, Employee relations, and Customer relations. From 2001 onwards, additional measures were included relating to the Environment, Diversity, and Non-US operations. In each social category, the ratings indicate a firm's "strengths" and "concerns" on a 1-5 scale, as identified by KLD research. To arrive at a score in each category, the "concerns" score is subtracted from the "strengths" score. The Corporate Citizenship scores for 2000-2002 are derived from KLD ratings averaged over a three-year period "to avoid one-year blips in performance" (in the same manner described above for Total return to shareholders). In subsequent years, a single year's KLD ratings are employed.

To standardize, each component is measured as the number of standard deviations above or below the mean. Then, each firm's Corporate Citizenship score is obtained by taking an unweighted average of the standardized components. The firms are ranked according to this composite, yielding a provisional Top 100. In a final step, a selection committee undertakes a LexisNexis database search of news sources for each company. Where this search reveals a significant scandal or impropriety not otherwise detected, a recommendation is made for the firm to be excluded from the final Top 100. It appears that in most years a handful of companies were dropped at this stage, although it is worth noting that companies which the authors consider to have committed minor sins are not summarily deleted. ${ }^{7}$

We obtained data from Datastream on all firms that were Top 100 constituents at any time during the sample period for the following variables: stock price total return indices (i.e. with dividends added back), market value of equity, book value, and industry code. We excluded investment trusts, and companies for which either the Datastream codes or one of the required variables was missing. We were able to employ a total of 98 or 99 out of the possible 100 firms in each sample year. ${ }^{8}$

\footnotetext{
${ }^{7}$ The lists of the top 100 companies for all of the years since the survey was first conducted (2000) are available from www.business-ethics.com/BE100_all.

${ }^{8}$ Given that "good firms" are unlikely to turn bad overnight, one may expect a strong degree of persistence in the profiles, with many firms being highly rated for several years in a row. Correlations between scores in contiguous years range from 0.7 to 0.87 , indicating a reasonably high degree of stability in the scores given for firms that remain within the Top 100 for at least two consecutive years. However, if a firm receives a score that places it within the Top 100 firms in a particular year, there is only a 64\% probability on average that it will still remain in the Top 100 the following year.
} 


\section{Methodology}

Our analysis of the impact and financial usefulness of the US "100 Best Corporate Citizens" scores is conducted in two parts, in a similar vein to Filbeck and Preece (2003b). The first part examines the market impact of the announcements over a 21-trading day window surrounding the date that the scores are published each year. Second, we also consider whether there is any information in the announcements that can be usefully employed to earn abnormal profits in the longer run. The techniques employed to examine the post-announcement impacts over both horizons are described in the following subsections.

\subsection{Short-run Price Impacts}

We determine the price impact of new survey announcements using a standard event study approach. The date of announcement of the new scores varies from one year to another, but is usually around March-April ${ }^{9}$. The announcement date is defined as day $t$, and we consider the abnormal returns (relative to the S\&P 500 index returns) on days $t-10$ to $t-1$ (to determine whether there could be any anticipation or leakage of information contained in the survey results) and then on days $t$ to $t+10$ (to determine whether there is any lagged impact or slow incorporation of any information contained in the survey data). We compute abnormal returns on each day within the event window, and the cumulative returns from day $t-10$ to day $t-1$ and from day $t$ to $t+10$. Statistical significance of the abnormal returns can be determined using the conventional $t$-statistic of the form

$$
\text { tstat }_{t}=\frac{\bar{A} \bar{R}_{t}}{\sigma\left(A R_{t}\right) / \sqrt{n_{t}}}
$$

where $\bar{A} \bar{R}_{t}$ is the mean cumulative abnormal return in year $t, \sigma\left(A R_{t}\right)$ is the cross-sectional standard deviation of abnormal returns in year $t$, and $n_{t}$ is the number of firms in the portfolio in year $t$.

Barber and Lyon (1997) have suggested that positive skewness in the cross-sectional distribution of abnormal returns can cause biases in the estimated test statistics. ${ }^{10}$ More specifically, it will cause oversizing for lower-tailed tests and a loss of power for upper-tailed tests. Lyon et al.(1999) propose to deal with this using a skewness-adjusted $t$-statistic of the form

$$
\text { tstat }_{s a, t}=\sqrt{n_{t}}\left(S_{t}+\frac{1}{3} \hat{\gamma}_{t} S_{t}^{2}+\frac{1}{6 n_{t}} \hat{\gamma}_{t}\right)
$$

where $S_{t}=\frac{\bar{A} \bar{R}_{t}}{\sigma\left(A R_{t}\right)}, \hat{\gamma}_{t}$ is the coefficient of skewness in the abnormal return distribution in year $t$, and all other notation is for (1). However, the problems associated with the skewed distribution described above

\footnotetext{
${ }^{9}$ The precise announcement dates each year are March 27, 2000; March 21, 2001; April 22, 2002; March 31, 2003; May 3, 2004.

${ }^{10}$ We also experimented with a sample matching approach, involving randomly selecting a matching, non-Top 100 firm for each Top 100 firm, and rebalancing each month. However, given the relatively small sizes of some of the event portfolios we investigate (e.g. the portfolio of firms dropping out of the Top 100), this approach yielded unstable results as a result of the idiosyncratic risk in the reference portfolios, and we therefore do not report these results.
} 
are only partially mitigated by the use of (2) rather than (1), and Lyon et al. recommend bootstrapping this test statistic. We follow this suggestion, drawing 2,000 bootstrapped samples of size $n_{t} / 4$ from the crosssection of abnormal returns, and we use these to form the critical values for determining the significance or otherwise of the test statistics derived from (2).

One possible explanation of an announcement effect is if changes in social responsibility scores lead institutional fund managers to rebalance their portfolios. In particular, ethical mutual index tracker funds may cause net buying (selling) pressure for stocks of the firms whose social performances have improved (worsened), or where firms previously failed (passed) ethical screens but now pass (fail). However, such a rationalization is not highly plausible in our case since the social indicators upon which the Business Ethics scores are based are already public information at least one year old. Therefore, any announcement impact must result from a perception among investors that the "gold seal" of the "100 Best Corporate Citizens" accolade represents useful new information. Possibly, the publicity that the publication of the Top 100 results generates for included firms causes an increase in demand for their stock even in the absence of genuinely new information. There is evidence that retail investors in particular (who are unlikely to have access to the KLD component CSP measures) are more likely to buy stocks whose names they already know (Barber and Odean, 2002), and thus the marketing impact of Top 100 membership serves to put these stocks at the forefront of investors' minds when they come to rebalance or add to their equity portfolios.

\subsection{The Long-run Profitability of Trading on Information in the Most Admired Companies Survey}

We determine the profitability of trading in the "100 Best Corporate Citizens" by forming various portfolios on the first working day of the month following publication of the survey, and holding them for one year. We assume that equally weighted portfolios are formed in each case, since this is likely to lead to increased power in the statistical tests relative to value-weighting (see Loughran and Ritter, 2000). ${ }^{11}$

There has been an ongoing debate in the literature concerning whether cumulative abnormal returns (CAR) or BHAR are preferable. Fama (1998) suggests that the latter are considerably more subject to the "bad model problem" because any errors in the calculation of the expected return are compounded, and may give misleading indicators of the speed of post-event price reaction. Consequently, we employ returns separately for each month in the year following the public announcement of the most admired firms, and we then sum them to obtain the CAR.

The efficient markets hypothesis would suggest that equity prices should only react to new information. Consequently, it is not immediately obvious whether continued presence in the Top 100 represents new information or not. It may be the case that appearance within the Top 100 firms for two consecutive years

\footnotetext{
${ }^{11}$ Our performance figures do not allow for transactions costs, although these are likely to be relatively trivial since trading would occur only once a year and almost all of the companies with high scores are large.
} 
does not constitute particularly useful information for investors, since the marginal news value will be relatively small. Or, it may be that continued presence in the Top 100 is the corporate equivalent of winning an Oscar, so that even repeatedly it is still highly prized, since the turnover of highly rated firms is more than one-third per year. In order to investigate this, as well as examining the performance of an equally weighted portfolio of all firms within the Top 100, we examine several other portfolios to determine whether investors focus on the change in the ranking of firms. These are detailed below.

It is important to allow for firm characteristics when examining the performance of the "100 Best Corporate Citizens," since highly admired firms were found typically to be large, glamour stocks. As Antunovich and Laster (2000) point out, the Fama-French (1992) study and associated work has suggested that such firms are likely on average to perform poorly. Thus we wish to examine the impact of firm characteristics on the profitability of the various one-year holding strategies described below. So, suppose we observe that companies ranking reputationally in the Top 100 yield large negative abnormal returns. Is this exceptional performance a feature of new information that was not already available in standard firm characteristics? Or does it arise, for example, because such firms are large and large firms tend to yield lower returns than small firms? In order to answer this question, we employ three methods.

First, as a summary indicator of the impact of being listed in the Top 100 firms on the next year's returns, we regress the cumulative abnormal return in a given year on a dummy variable taking the value 1 if the firm is in the Top 100 and 0 otherwise. The sample for this regression comprises all firms within the S\&P 1500 index at any time during the 5-year period, and we employ a pooled sample containing year dummies for each of the 5 years. We include in this regression the firm's market value ("CAP") and priceto-book value ("PTBV") prior to the announcement of the scores. We also estimate a regression containing the actual score together with CAP, PTBV, and the year dummies using a reduced sample comprising all companies in the Top 100 at any point during the 5-year period, a total of 457 firm-years:

$r_{i t}=\alpha_{1} P T B V_{i, t}+\alpha_{2}$ CAP $_{i, t}+\alpha_{3}$ SCOREDUM $_{i, t}+\alpha_{4} D 2000_{t}+\alpha_{5} D_{2001_{t}}+\alpha_{6} D_{2002_{t}}+\alpha_{7} D_{2003_{t}}+\alpha_{8} D_{2004_{t}}+u_{t}(3)$

Or

$r_{i t}=\beta_{1} P T B V_{i, t}+\beta_{2} C A P_{i, t}+\beta_{3} O V E R A L L_{i, t}+\beta_{4} D 2000_{t}+\beta_{5} D 2001_{t}+\beta_{6} D 2002_{t}+\beta_{7} D 2003_{t}+\beta_{8} D 2004_{t}+u_{t}$

where $r_{i t}$ are the returns to stock $i$ in year $t$ (where each year runs from the survey result announcement day), SCOREDUM is a dummy variable taking the value 1 if the firm is in the Top 100 and 0 otherwise, OVERALL is the firm's overall " 100 Best Corporate Citizens" score, and $u_{t}$ is a disturbance term.

Second, we run the regression each year to examine the average impact of firm characteristics on nextperiod returns:

$$
r_{i t}=\beta_{1}+\beta_{2} P T B V_{i, t}+\beta_{3} C A P_{i, t}+\beta_{4} r_{i t-1}+u_{i, t}
$$

We therefore regress, separately for each year, the annual returns on a constant, the stocks, size ("CAP"), price-to-book ("PTBV"), beta, and the previous year's return. While this approach is different to that of Fama and French (1993), described below, we believe that this represents a useful way to construct 
expected returns for the Top 100 firms. ${ }^{12}$ The regression is run for each survey year separately using all firms in our dataset, which comprises all firms that have been within the Top 100 at any point during the 5 -year period plus all other firms that were S\&P 500 constituents at any point during the sample period. The estimated regression parameters will show the relationship between average stock returns and firm characteristics. We then take these parameter values and multiply them by the equally weighted average values of the characteristics (i.e. PTBV, CAP, previous return) for companies that are in the Top 100. This enables us to answer the question, "Given the average characteristics of the companies in the Top 100, what returns would have been expected based on the relationship between characteristics and returns for firms that were not in the Top 100?"13 This approach is repeated separately to determine the expected returns for stocks: 1) within the Top 100;2) with rising ranks within the Top 100; 3) with falling ranks within the Top 100; 4) dropping out of the Top 100; 5) entering the Top 100; 6) in the Top 100 but not in the S\&P 500. This final portfolio is investigated in order to further determine the impact of firm size and previous exposure on the performance of the highly rated firms. As described above, the survey producers consider all firms in the S\&P 500 plus 150 other firms "chosen for industry balance and social strength,"14 and it is therefore of interest to consider whether the returns to firms outside the S\&P 500 are different from those within it.

As a third approach to examining the impact of firm characteristics on the performance of the highly rated firms, we adopt the procedure developed by Fama and French (1993). This involves estimating a timeseries regression of the portfolio returns (for example, for the equally weighted portfolio of the Top 100 companies by overall score) on the market excess return, and the portfolios formed on size, book-tomarket and previous return:

$$
r_{t}=\beta_{1}+\beta_{2} R M R F_{t}+\beta_{3} S M B_{t}+\beta_{4} H M L_{t}+\beta_{5} M O M_{t}+u_{t}
$$

where $r_{t}$ is the portfolio return, $R M R F$ is the excess return on the market (return on all NYSE, AMEX, and NASDAQ stocks minus the 1-month T-bill yield), SMB is the average return on the three small portfolios minus the average return on the three large portfolios, $H M L$ is the average return on the two value portfolios minus the average return on the two growth portfolios, and $M O M$ is the average return on the

\footnotetext{
${ }^{12}$ Note that this regression does not incorporate a CAPM beta term. Fama and MacBeth (1973) and a number of more recent studies have highlighted the errors-in-variables problem that may plague a regression such as (5) if a beta term is included since this variable would be an estimated rather than an actual quantity. Therefore, given the large number of studies documenting the limited power of beta in explaining the cross-sectional variation in stock returns, we omit it from the equation. An examination of the results where beta is included in the regression suggests only very minor differences. Sensitivity to market risk will be incorporated into the framework when the Fama-French (1993) procedure is used subsequently.

${ }^{13}$ Our regression-based approach is somewhat different to the "sample-matching" procedure employed by Antunovich and Laster (2000). The latter method would involve multi-way sorting the control sample of firms into quintiles or deciles based on the various characteristics, which may still leave the sorted portfolio with somewhat different characteristics to the firm it is supposedly matched with. By contrast, our technique should ensure that the expected return for a firm with these characteristics is calculated exactly.

${ }^{14}$ In 2003 and 2004, the survey employed the Russell 1000 rather than the S\&P 500 as a basis for determining the universe of firms.
} 
two high prior return portfolios minus the average return on the two low prior return portfolios. ${ }^{15}$ The regressions are run on the 60 months of post-announcement returns (12 months for each of the 5 surveys), except for portfolios formed on the change in the rank from one year to the next, etc., where there are only 4 years of returns (48 observations).

\section{Results}

\subsection{Short-run Price Impact}

The stock return impact of announcements that a firm is included in the Top 100 is described in Table 1. The first two rows below the headers present the abnormal percentage returns (constructed by subtracting the S\&P 500 returns) for all companies included in the Top 100 for the event period from 10 days before the announcement to 10 days after. The results suggest that the markets appear to view inclusion in the Top 100 positively. The pre-announcement cumulative abnormal returns are on average positive (although not significantly so) for the 2 trading weeks before publication. The average abnormal return during the 2week run-up period is $1.3 \%$, and it is positive for 4 of the 5 years on day $t$, averaging $0.2 \%$. Only for 2000 was the announcement day abnormal return negative. In that year, large positive and significant returns were observed on days $(t-10)$ to $(t-7)$, suggesting a possible leakage of the results of the survey during that year resulting in a pre-announcement rather than a post-announcement price impact. The cumulative returns in 2000 are particularly large (2.8\% for the two trading weeks before the announcement and $2.9 \%$ after); this may be purely coincidental, or it may be that the impact of the survey results was the most potent for this first year of publication. Therefore, the news impact value of being in the Top 100 is likely to have been at its largest during that year.

In order to investigate whether the mere presence in the Top 100 is the most important attribute, or whether the firm's relative position is the key indicator in determining the equity market's response, we also examine the abnormal returns around the announcement for companies whose ranks have risen within the Top 100 and for those who have fallen, respectively. The cumulative abnormal returns are larger for companies whose ranks had risen $(1 \%$ and $0.8 \%$ in the pre-announcement and post-announcement windows respectively) than for those whose ranks had fallen $(0.9 \%$ and $-0.6 \%$, respectively). The announcement day returns for the portfolio of companies with rising ranks is positive for all years, while it is positive for 3 of the 4 years in the case of the portfolio of companies with falling ranks.

The most salient features of these results are the lack of statistical significance of the majority of event day, pre- and post-announcement abnormal returns. The only portfolio for which there is some evidence for statistically reliable announcement effects is for that comprising non-S\&P 500 firms, perhaps resulting from the additional newsworthiness of Top 100 inclusion in such cases. There is a large announcement effect in 2000, where the Top 100 firms yielded a cumulative abnormal return of almost $6 \%$ over the

\footnotetext{
${ }^{15}$ These variable descriptions and the factor series are obtained from French's web site, http://mba.tuck.dartmouth.edu/pages/faculty/ken.french/Data_Library. We thank Ken French for making these data available.
} 
month surrounding publication. One might have expected such a result given that this was the first year that the survey was produced, implying new information for all 100 stocks, rather than the relatively diluted impact of an announcement of a further vintage of ratings, some of which will be similar to those of the previous year.

That the announcement effects are only modest is, perhaps, hardly surprising. Given that the scores are supposed to provide an assessment of the inherent quality of a firm, the announcements are unlikely to lead to large and immediate price pressures. Therefore, while this result is consistent with there being fairly small information content in the scores, or in relative changes to the ranks of firms in the Top 100, two alternative scenarios would lead to the same finding. First, it is equally possible that investors respond with a much longer lag to the Business Ethics "100 Best Corporate Citizens" survey, taking the scores into account in their decision-making process when they next rebalance their portfolios. Second, even if investors ignore the survey data, the scores may still have useful information content if, when viewed ex post, the stock of good corporate citizens yields higher returns than that of less highly rated firms. In order to investigate this issue further, we now turn our attention to an assessment of the relationship between being a good corporate citizen and stock returns over the longer run.

\subsection{Long-run Performance of Most Admired Companies}

Table 2 presents the results of a pooled regression of the stock return on a set of year dummy variables and an indicator dummy variable taking the value 1 if the company is in the Top 100 and 0 otherwise for our sample of all companies with scores and all companies that were S\&P 1500 constituents at some point during the 5-year period (a total of 1,129 firm-years), as described in (3) above. The regression gives a slope estimate of -8.20 with a $t$-ratio of -4.46 , indicating that, on average, companies within the Top 100 list earn returns that are a statistically significant $8.2 \%$ per year lower than those outside the Top 100 . Allowing for the impact of size and style (CAP and PTBV, respectively) reduces this degradation in average performance to $2.62 \%$ per annum, and it becomes statistically insignificant.

The second panel of Table 2 presents the results of a similar regression where returns are now regressed on the actual score rather than the indicator variable, plus the year dummies, as described in (4). The sample is now all firms within the Top 100 in at least one year (457 firm-years). Each 1-point increase in score leads to a statistically significant average reduction in returns of $16.64 \%$ ( $t$-ratio -2.55 ). While the mean score varies somewhat from one year to another, the spread of scores (i.e. the range from minimum to maximum) across Top 100 firms is fairly constant at around 1 unit, and thus this difference in returns is financially quite considerable. Again, inclusion of size and style as independent variables in the regression model reduces the magnitude of the parameter (to $-5.6 \%$ ), and renders it statistically insignificant.

Table 3 presents the abnormal returns for the six equally weighted portfolios of companies averaged over all years in the sample. The most salient feature of these results is that firms listed in the "100 Best 
Corporate Citizens" survey underperform the market as a whole in the long term, irrespective of whether the firm's relative position in the Top 100 has risen or fallen compared with the previous year. The cumulative abnormal returns for a portfolio comprising all companies in the Top 100 is negative for 4 of the 5 years for which the survey has been conducted, averaging $-3.3 \%$ per year. Similarly, the abnormal returns for rising and for falling firms within the Top 100 are consistently negative for all but one year, with average annual abnormal returns of $-7.6 \%$ in the latter case. Returns appear to be somewhat worse for the first 2 months after announcement, with average negative abnormal returns of at least $2 \%$, perhaps reflecting a reversal following over-exuberance on the days around the announcement. In fact, abnormal returns for the all-companies sample are negative for at least one of the 2 months following the announcement for every year.

The non-S\&P companies within the Top 100 show much-improved performance compared to other highly rated firms. The average annual abnormal return for such firms over the 2000-2004 period is $+7.2 \%$, and is never negative. The cumulative abnormal return over the year following the first survey results in 2000 is a remarkable $23 \%$, and is positive for 9 of the 12 months. This result plausibly suggests that the market reacts much more strongly to the news that a non-S\&P 500 company is one of the country's Best Corporate Citizens. Such firms are likely to be significantly smaller and much less widely tracked by analysts. Indeed in 2004, companies in the S\&P 500 with CSR scores that ranked them in the Top 100 had market capitalizations that were on average 12 times $\operatorname{larger}{ }^{16}$ than those with scores in the Top 100 but outside the S\&P 500. However, fascinatingly, the value indicators (PTBVs) of the six portfolios are only slightly smaller than those of the S\&P 500, and are around 10 times larger than those of the average firm in the S\&P 1500. Thus, even the relatively small firms that newly enter the Top 100 or that are Top 100 members but outside the S\&P 500 can be categorized as "growth firms."

As suggested above, large capitalization and growth are characteristics that are likely to make the Business Ethics list firms poor performers on average, so can such firm characteristics explain in full the negative abnormal performance of firms in the Top $100 ?{ }^{17}$ In order to address this question, Table 4 presents the abnormal returns given company characteristics (size, PTBV, and momentum) for various portfolios of firms, as defined by (5). Similarly, Panel B presents the abnormal returns given the industrial composition of various portfolios.

It is evident that the expected returns given firm characteristics and the actual returns are reasonably close together in many instances, so that the abnormal returns given characteristics are much closer to 0 than the abnormal returns based on a market index. Companies with overall scores that place them within the Top 100 earn average cumulative returns of $11.1 \%$ for the year following the announcement, while their characteristics merited a return of $13.4 \%$, an "abnormal return" of $-2.3 \%$, a less negative figure than the

\footnotetext{
${ }^{16}$ And the median firm is 10 times larger.

${ }^{17}$ As Table 3 shows, around 30\% of the Top 100 companies are drawn from outside the S\&P 500.
} 
characteristic-unadjusted abnormal return (relative to the S\&P 500) of $-3.3 \%$. Similarly, the negative abnormal returns of companies within the Top 100 whose ranks are falling or whose ranks are rising, can be in large part explained by their characteristics. The considerable temporal variation in the performance of good citizens is clearly evident, a result that corroborates Statman's (2006) findings.

An interesting result can be seen by examining the last two rows of Panel A in Table 4. For firms entering the Top 100, or for firms that are in the Top 100 but not included in the S\&P 500, their average annual returns are higher than would be expected given their firm characteristics by around $12 \%$ and lower than would be expected by $6 \%$ respectively, suggesting that the results of the survey can have useful value for fund managers when considered in the appropriate way. In the case of Top 100 scoring, non-S\&P 500 firms, the information content of an announcement that these firms are highly rated represents a much greater piece of news than where the stock is already widely followed and is already part of most passive fund managers' portfolios. Thus, the "radar" effect of being in the Top 100 makes investors more aware of these smaller company stocks; however, this effect is not sufficient to offset the apparently poor performance of such firms. By contrast, the publicity associated with a company newly entering the Top 100 , from both the firm itself and the media more generally, has the impact of renewing investors' awareness of the existence of the stock and informing them that the underlying firm is a "good" one.

Our findings are rather different to those by Antunovich et al. (2000) and Filbeck et al. (1997), where high scores on the Fortune survey led to positive abnormal returns. As well as the differing methodology used to construct abnormal returns, this difference in results may also be attributable to the relatively larger readership of this magazine compared with Business Ethics. However, our results are consistent with those of Chung et al. (2003) where the Fortune survey was again used but with a different approach to measuring outperformance. This paper's findings are also consistent with those of Allen and Kask (1997) , where the KLD social responsibility components that comprise part of the Business Ethics scores are employed.

Finally, Table 5 gives the results of a Fama-French (1993)-style regression model, also including a momentum term. The slope parameter estimates in the second row suggest that firms in the Top 100 have negative loadings on the market return, size, value, and momentum terms, although only size and momentum are statistically significant. The size and value signs are as expected since the highly rated firms are large, glamour stocks, but the negative momentum term is surprising, and suggests that highly rated firms tend typically not to have stock price momentum. Of most relevance is a comparison of the intercept terms in the regressions without the factors (i.e. $\left.\alpha_{1}\right)$ and including the factors $\left(\beta_{1}\right)$. For the first three portfolios (all firms in the Top 100; firms with falling ranks; firms with rising ranks), the intercept parameter is brought closer to zero by the inclusion of the factors. To illustrate, for all firms in the Top 100 , the intercept (representing the average monthly abnormal return) falls from -0.28 to -0.09 . Only in the second of the three cases is the intercept initially significant at the $5 \%$ level, and it becomes just 
significant at the $10 \%$ level upon inclusion of the factors in the model. We therefore conclude that the poor stock performance of the Best Corporate Citizens is partially attributable to their possessing the characteristics of assets that tend to yield low returns. For the portfolios comprising firms that fell out of or that entered the Top 100, allowing for these characteristics does not markedly alter the average returns. The average monthly abnormal return for firms dropping out of the Top 100 is $-0.45 \%$ excluding the factors, but is $-0.44 \%$ after incorporating them; for firms entering the Top 100 , the figures are $+0.32 \%$ and $+0.44 \%$, respectively. Unlike the Top 100 firms as a whole, those firms outside of the S\&P 500 appear to be small firms with positive loadings on momentum. Consequently, after allowing for these characteristics, the highly significant average abnormal monthly return of $0.6 \%$ reduces to a statistically insignificant but financially meaningful $0.2 \%$.

\section{Conclusions}

This study has considered the financial information content of the Business Ethics "Best 100 Corporate Citizens" survey that has been conducted annually since 2000. The survey rates firms according to several attributes of relevance to the various stakeholder groups touched by the firm's activities. We find that firms included in the Top 100 generate small but positive cumulative abnormal returns in a 21 -trading day window around the announcement of the survey results, although they are mostly not statistically significant.

Considering the longer-term performance of the highly rated firms, we find that purchasing an equally weighted portfolio comprising all of the Top 100 stocks would generate annual returns an average of 3.3\% below those of the S\&P 500, and buying stocks whose ranks had risen or whose ranks had fallen within the Top 100 would similarly have underperformed the index. Firms that drop out of the Top 100 earn even lower abnormal returns, while firms that newly enter the Top 100 earn positive abnormal returns, such that an arbitrage strategy of buying the latter and short selling the former could be highly profitable.

However, when we allow for the financial characteristics of the firms (e.g. value, size, momentum, and sector) in various ways, the returns to the companies in the Top 100 are not far short of those that would have been expected given those characteristics. Only the portfolio of firms that newly enter the Top 100 show reasonably large positive abnormal returns after allowing for size and style, and even these are mostly not statistically significant. The benchmarking issue is crucial, but we find that a standard market index such as the S\&P 500 is a reasonable choice as a yardstick since it has broadly similar size and style characteristics to the typical highly rated firm. Firms that are regarded as good corporate citizens comprise $70 \%$ large firms with high price-to-book ratios - traits that typically imply poor stock returns. Our results are thus consistent with the findings of Antunovich and Laster (2000).

Why should being newly thought of as a good corporate citizen lead to strong stock returns but continuing to be part of this list lead to negative abnormal returns? Our findings are most consistent with the 
behavioral explanations put forward in the over-reaction literature (e.g. DeBondt and Thaler, 1985, 1987). It may be that the publicity associated with first being included in the Top 100 together with investors taking into account the information contained in the survey when making their stock selections pushes stock prices higher by their demand. Eventually, the euphoria associated with being labeled as a good corporate citizen dies down, resulting in a reduction in demand for the stock. It may also be the case that good corporate citizenship is negatively correlated with future stock performance irrespective of whether investors read the survey results, which would justify the low returns of the admired firms. Further research is warranted to distinguish between these competing explanations.

\section{References}

Allen, G. and Kask, S. (1997) "Socially Responsible Firms: Financial and Market Performance” Journal of Business and Economic Perspectives 23(2), 86-96.

Antunovich, P. and Laster, D.S. (2000) “Do Investors Mistake a Good Company for a Good Investment?" Journal of Investing Spring.

Antunovich, P., Laster, D.S., and Mitnick, S. (2000) “Are High-quality Firms also High-quality Investments?" Current Issues in Economics and Finance 6, 1-6.

Barber, B.M. and Lyon, J.D. (1997) "Detecting Long-run Abnormal Stock Returns: The Empirical Power and Specification of Test Statistics" Journal of Financial Economics 43, 341-372.

Barber, B.M. and Odean, T. (2002) "All that Glitters: The Effect of Attention and News on the Buying Behavior of Individuals and Institutional Investors" University of California, Davis, Mimeo.

Brammer, S.J., Brooks, C., and Pavelin, S. (2006) "Corporate Social Performance and Stock Returns: UK Evidence from Disaggregate Measures" Financial Management 35(3), 5-25.

Brammer, S.J. and Millington, A.I. (2005) "Corporate Reputation and Philanthropy: An Empirical Analysis" Journal of Business Ethics 61(1), 29-44.

Carroll, A. B. 1999. "Corporate Social Responsibility - Evolution of a Definitional Construct” Business and Society 38, 268-295.

Carhart, M. (1997) “On Persistence in Mutual Fund Performance” Journal of Finance 52, 57-82.

Chen, H-L and DeBondt, W. (2004) "Style Momentum within the S\&P 500 Index" Journal of Empirical Finance 11, 483-507.

Chung, S.Y., Eneroth, K., and Schneeweis, T. (2003) "Corporate Reputation and Investment Performance: The UK and US Experience" Research in International Business and Finance 17, 273-291.

Cox, P., Brammer, S., and Millington, A. (2004) "An Empirical Examination of Institutional Investor Preferences for Corporate Social Performance" Journal of Business Ethics 52, 27-43.

DeBondt, W.F.M. and Thaler, R.H. (1987) "Further Evidence on Overreaction and Stock Market Seasonality" Journal of Finance 42, 557-581.

DeBondt, W.F.M. and Thaler, R.H. (1985) “Does the Stock Market Overreact?” Journal of Finance 40, 793-805.

Derwall, J., Gunster, N., Bauer, R., and Koedojk, K. (2004) "The Eco-Efficiency Premium Puzzle" Erasmus University Working Paper.

Fama, E. (1998) "Market Efficiency, Long-term Returns, and Behavioral Finance” Journal of Financial Economics 49, 283-306.

Fama, E. and French, K. (1993) "Common Risk Factors in the Returns on Stocks and Bonds" Journal of Financial Economics 33, 3-56.

Fama, E. and French, K. (1992) “The Cross-Section of Expected Stock Returns” Journal of Finance 47, 427-465.

Fama, E. and MacBeth, J. (1973) "Risk, Return and Equilibrium: Empirical Tests" Journal of Political Economy 81(3), 607-636.

Filbeck, G., Gorman, R., and Preece, D. (1997) “Fortune's Most Admired Firms: An Investor's Perspective” Studies in Economics and Finance 18, 74-93.

Filbeck, G. and Preece, D. (2003a) "Announcement Effects of the Working Mother Annual Survey of FamilyFriendly Firms" Journal of Investing 12(3), 87-95.

Filbeck, G. and Preece, D. (2003b) "Fortune's Best 100 Companies to Work for In America: Do they Work for Shareholders?" Journal of Business Finance and Accounting 30, 771-797.

Graves, S.B. and Waddock, S.A. (1994) "Institutional Owners and Social Performance" Academy of Management Journal 37, 1034-1046.

Grossman, B. and Sharpe, W. (1986) "Financial Implications of South Africa Divestment" Financial Analysts Journal, July/August, 15-29. 
Hamilton, S., Jo, H. and Statman, M. (1993) "Doing Well While Doing Good? The Investment Performance of Socially Responsible Mutual Funds" Financial Analysts Journal 49, 62-66.

Jones, R. and Murrell, A. (2001) "Signaling Positive Corporate Social Performance" Business and Society 40, 59-78.

Loughran, T. and Ritter, J.R. (2000) "Uniformly Least Powerful Tests of Market Efficiency" Journal of Financial Economics 55, 361-389.

Lyon, J.D., Barber, B.M., and Tsai, C.-L. (1999) "Improved Methods for Tests of Long-run Abnormal Stock Returns" Journal of Finance 54(1), 165-201.

Maignan, I., \& Ferrell, O.C. 2000. "Measuring Corporate Citizenship in Two Countries: The Case of the United States and France" Journal of Business Ethics 23, 283-297.

Matten, D. and Crane, A. (2005) "Corporate Citizenship: Toward an Extended Theoretical Conceptualization" Academy of Management Review, 30(1), 166-179

McLachlan, J. and Gardner, J. (2004) “A Comparison of Socially Responsible and Conventional Investors” Journal of Business Ethics 52(1), 11-25.

Moskowitz, M. (1972) "Choosing Socially Responsible Stocks" Business and Society 1, 71-75.

Nayak, S. and Prabhala, N.R. (2001) "Disentangling the Dividend Information in Splits: A Decomposition using Conditional Event Study Methods" Review of Financial Studies 14(4), 1083-1116.

Rudd, A. (1981) "Social Responsibility and Portfolio Performance" California Management Review, 23(4), 55-61.

Scholtens, B. (2005) "Style and Performance of Dutch Socially Responsible Investment Funds" Journal of Investing,14(1), 63-72.

Schroder, M. (2004) "The Performance of Socially Responsible Investments: Investment Funds and Indices" Financial Markets and Portfolio Management 18(2), 122-142.

Sherfin, H. and Statman, M. (1995) "Making Sense of Beta, Size and Book-to-Market" Journal of Portfolio Management 21, 26-34.

Sherfin, H. and Statman, M. (1997) "Behavioral Portfolio Theory" Mimeo, Santa Clara University.

Statman, M. (2000) "Socially Responsible Mutual Funds" Financial Analysts Journal 56, 30-39.

Statman, M. (2006) "Socially Responsible Indexes: Composition, Performance and Tracking Errors" Journal of Portfolio Management 32(3), 100-109.

Vergin, R.C. and Qoronfleh, M. (1998) "Corporate Reputation and the Stock Market” Business Horizons 41, 19-26.

Waddock, S.A. and Graves, S.B. (1999) "Assessing the Link Between Corporate Governance and Social/Financial Performance" International Association for Business and Society Conference Proceedings. 
Table 1: Announcement Event Window Returns and $t$-ratios for Various Portfolios

\begin{tabular}{|c|c|c|c|c|c|c|c|c|c|c|c|c|c|c|c|}
\hline & & 2000 & & & 2001 & & & 2002 & & & 2003 & & & 2004 & \\
\hline & $(t-10, t-1)$ & $\underline{t}$ & $(t+1, t+10)$ & $(t-10, t-1)$ & $\underline{t}$ & $(t+1, t+10)$ & $(t-10, t-1)$ & $\underline{t}$ & $\underline{(t+1, t+10)}$ & $(t-10, t-1)$ & $\underline{t}$ & $(t+1, t+10)$ & $(t-10, t-1)$ & $\underline{t}$ & $\underline{(t+1, t+10)}$ \\
\hline In Top 100 & $\begin{array}{c}2.80 \\
\{3.31\}^{* *}\end{array}$ & $\begin{array}{l}-0.65 \\
\{-2.50\}\end{array}$ & $\begin{array}{c}3.54 \\
\{4.39\}^{*}\end{array}$ & $\begin{array}{c}0.58 \\
\{0.74\}\end{array}$ & $\begin{array}{c}0 . \overline{6} 3 \\
\{2.32\}^{*}\end{array}$ & $\begin{array}{l}-1.74 \\
\{-1.57\}\end{array}$ & $\begin{array}{c}1.74 \\
\{3.67\}\end{array}$ & $\begin{array}{c}0 . \overline{2} 4 \\
\{1.30\}\end{array}$ & $\begin{array}{c}-0.15 \\
\{-0.20\}\end{array}$ & $\begin{array}{c}0.34 \\
\{0.68\}\end{array}$ & $\begin{array}{c}0 . \overline{6} 4 \\
\{3.75\}\end{array}$ & $\begin{array}{c}-0.41 \\
\{-0.85\}\end{array}$ & $\begin{array}{c}0.96 \\
\{2.39)^{* *}\end{array}$ & $\begin{array}{c}0.08 \\
\{0.55)\end{array}$ & $\begin{array}{c}-0.44 \\
\{-1.32\}\end{array}$ \\
\hline $\begin{array}{l}\text { With Ranks } \\
\text { Rising }\end{array}$ & - & - & - & $\begin{array}{l}1.06 \\
\{0.83\}\end{array}$ & $\begin{array}{c}0.47 \\
\{0.85\}\end{array}$ & $\begin{array}{l}-2.26 \\
\{-0.92\}\end{array}$ & $\begin{array}{l}1.71 \\
\{2.14\}\end{array}$ & $\begin{array}{c}0.23 \\
\{0.94\}\end{array}$ & $\begin{array}{l}1.92 \\
\{1.91\}\end{array}$ & $\begin{array}{c}-0.23 \\
\{-0.26\}\end{array}$ & $\begin{array}{c}0.27 \\
\{0.74\}\end{array}$ & $\begin{array}{c}0.46 \\
0.52\}\end{array}$ & $\begin{array}{l}1.03 \\
\{1.60\}\end{array}$ & $\begin{array}{l}-0.29 \\
\{1.18\}\end{array}$ & $\begin{array}{c}-1.43 \\
\{-2.20\}\end{array}$ \\
\hline $\begin{array}{l}\text { With Ranks } \\
\text { Falling }\end{array}$ & - & - & - & $\begin{array}{c}1.12 \\
\{0.81\}\end{array}$ & $\begin{array}{c}0.82 \\
\{1.94\}\end{array}$ & $\begin{array}{l}-0.06 \\
\{-0.01\}\end{array}$ & $\begin{array}{l}1.18 \\
\{1.54\}\end{array}$ & $\begin{array}{c}0.07 \\
\{0.21\}\end{array}$ & $\begin{array}{c}-3.10 \\
\{-1.40\}\end{array}$ & $\begin{array}{l}0.68 \\
\{0.97\}\end{array}$ & $\begin{array}{c}0.44 \\
\{2.35\}\end{array}$ & $\begin{array}{l}-0.52 \\
\{-0.93)\end{array}$ & $\begin{array}{c}0.59 \\
\{0.72\}\end{array}$ & $\begin{array}{c}-0.06 \\
\{-0.23\}\end{array}$ & $\begin{array}{c}-0.09 \\
\{-0.16\}\end{array}$ \\
\hline $\begin{array}{c}\text { Dropping out of } \\
\text { Top } 100\end{array}$ & - & - & - & $\begin{array}{c}4.68 \\
\{4.06\}\end{array}$ & $\begin{array}{c}0.42 \\
\{1.10\}\end{array}$ & $\begin{array}{c}2.58 \\
\{2.74\}\end{array}$ & $\begin{array}{l}-1.62 \\
\{-0.21\}\end{array}$ & $\begin{array}{c}0.74 \\
\{1.96\}\end{array}$ & $\begin{array}{c}-0.48 \\
\{-0.32\}\end{array}$ & $\begin{array}{c}0.20 \\
\{0.21\}\end{array}$ & $\begin{array}{c}-0.03 \\
\{-0.01\}\end{array}$ & $\begin{array}{c}-0.19 \\
\{-0.25\}\end{array}$ & $\begin{array}{c}-0.98 \\
\{-0.91\}\end{array}$ & $\begin{array}{c}-0.82 \\
\{-2.70\}^{* *}\end{array}$ & $\begin{array}{c}-0.74 \\
\{-0.92\}\end{array}$ \\
\hline Entering Top 100 & - & - & - & $\begin{array}{c}-0.20 \\
\{-0.16\}\end{array}$ & $\begin{array}{c}0.56 \\
\{1.16\}\end{array}$ & $\begin{array}{c}-3.12 \\
\{-1.59\}\end{array}$ & $\begin{array}{c}1.94 \\
\{2.38\}\end{array}$ & $\begin{array}{c}0.54 \\
\{1.36\}\end{array}$ & $\begin{array}{c}-0.40 \\
\{-0.31\}\end{array}$ & $\begin{array}{c}0.39 \\
\{0.46\}\end{array}$ & $\begin{array}{c}1.07 \\
\{3.78\}^{*}\end{array}$ & $\begin{array}{c}-0.79 \\
\{-0.71\}\end{array}$ & $\begin{array}{l}0.95 \\
\{1.47\}\end{array}$ & $\begin{array}{l}-0.07 \\
\{-0.22\}\end{array}$ & $\begin{array}{l}-0.10 \\
\{-0.17\}\end{array}$ \\
\hline $\begin{array}{l}\text { In Top } 100 \text { but } \\
\text { not in S\&P } 500\end{array}$ & $\begin{array}{c}4.24 \\
\{1.65\}\end{array}$ & $\begin{array}{c}-0.88 \\
\{-1.44\}\end{array}$ & $\begin{array}{c}2.09 \\
\{1.03\}\end{array}$ & $\begin{array}{c}0.76 \\
\{0.42\}\end{array}$ & $\begin{array}{c}1.22 \\
\{1.83\}\end{array}$ & $\begin{array}{l}-1.39 \\
\{-0.40)\end{array}$ & $\begin{array}{c}0.19 \\
\{0.12\}\end{array}$ & $\begin{array}{c}0.35 \\
\{0.82\}\end{array}$ & $\begin{array}{c}3.49 \\
\{2.17\} * *\end{array}$ & $\begin{array}{c}2.03 \\
\{1.35\}\end{array}$ & $\begin{array}{c}0.15 \\
\{0.33\}\end{array}$ & $\begin{array}{l}-1.63 \\
\{-0.77\}\end{array}$ & $\begin{array}{c}3.01 \\
\{2.69\} * *\end{array}$ & $\begin{array}{c}0.97 \\
\{2.37\}^{*}\end{array}$ & $\begin{array}{c}-0.62 \\
\{-0.82\}\end{array}$ \\
\hline
\end{tabular}

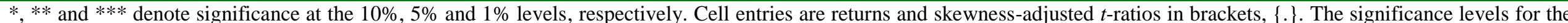
skewness-adjusted $t$-ratios are calculated using critical values from the bootstrapped statistics.

Table 2: Regression Results for the Impact of Being in the Top 100 on Returns

$r_{i t}=\alpha_{1} P_{T B} V_{i, t}+\alpha_{2}$ CAP $_{i, t}+\alpha_{3}$ SCOREDUM $_{i, t}+\alpha_{4} D_{2000_{t}}+\alpha_{5} D_{2001_{t}}+\alpha_{6} D_{2002_{t}}+\alpha_{7} D 2003_{t}+\alpha_{8} D_{2004_{t}}+u_{t}$

\begin{tabular}{cccccccc}
\hline$\alpha_{1}$ & $\alpha_{2}$ & $\alpha_{3}$ & $\alpha_{4}$ & $\alpha_{5}$ & $\alpha_{6}$ & $\alpha_{7}$ & $\alpha_{8}$ \\
\hline- & - & -8.20 & 15.69 & 29.53 & -9.02 & 51.66 & 10.97 \\
-0.09 & -0.0002 & -2.63 & 18.45 & 32.14 & -6.65 & 53.64 & 13.53 \\
$(0.02)^{* *}$ & $(0.00001)^{* *}$ & $(1.85)$ & $(0.84)^{* *}$ & $(0.83)^{* *}$ & $(0.82)^{* *}$ & $(0.82)^{* *}$ & $(0.82)^{* *}$ \\
\hline \multicolumn{6}{c}{$r_{i t}=\beta_{1} P T B V_{i, t}+\beta_{2} C A P_{i, t}+\beta_{3} O V E R A L L_{i, t}+\beta_{4} D 2000_{t}+\beta_{5} D 2001_{t}+\beta_{6} D 2002_{t}+\beta_{7} D 2003_{t}+\beta_{8} D 2004_{t}+u_{t}$} \\
\hline$\beta_{1}$ & $\beta_{2}$ & $\beta_{3}$ & $\beta_{4}$ & $\beta_{5}$ & $\beta_{6}$ & $\beta_{7}$ & $\beta_{8}$ \\
\hline- & - & -16.64 & 63.07 & 23.28 & 2.83 & 56.07 & 18.89 \\
-0.36 & -0.0001 & $(6.51)^{*}$ & $(23.87)^{* *}$ & $(5.49)^{* *}$ & $(5.19)$ & $(6.21)^{* *}$ & $(5.86)^{* *}$ \\
$(0.08)^{* *}$ & $(0.00003)^{* *}$ & -5.60 & 39.89 & 33.18 & 11.99 & 59.43 & 27.38 \\
\hline
\end{tabular}

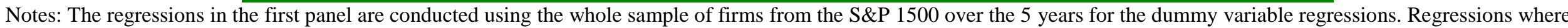

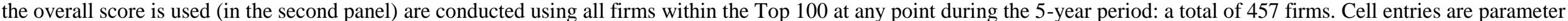
estimates with standard errors in parentheses; * and ** denote significance at the 5\% and $1 \%$ levels, respectively. 
Table 3: Abnormal Returns for 12 Months After Score Announcements

\begin{tabular}{|c|c|c|c|c|c|c|c|c|c|c|c|c|c|c|}
\hline $\begin{array}{l}\text { Average } \\
\text { number } \\
\text { of firms }\end{array}$ & 1 & 2 & 3 & 4 & 5 & 6 & 7 & 8 & 9 & 10 & 11 & 12 & $\begin{array}{c}\text { CAR } \\
\text { over year }\end{array}$ & $\begin{array}{c}\text { Time-Series } \\
\text { Standard } \\
\text { deviation }\end{array}$ \\
\hline \multicolumn{15}{|c|}{ Abnormal Returns for all Companies with a Score } \\
\hline 98 & -1.09 & -0.77 & 1.08 & 0.43 & -1.12 & 0.02 & -0.36 & -0.32 & -0.38 & 0.16 & -1.01 & 0.04 & -3.33 & 0.67 \\
\hline \multicolumn{15}{|c|}{ Abnormal Returns for Companies whose Ranks have Risen } \\
\hline 22 & -1.79 & -1.55 & 1.40 & 0.90 & 0.01 & -0.29 & -1.02 & -1.07 & -1.30 & 0.17 & -0.18 & 0.24 & -4.48 & 0.99 \\
\hline \multicolumn{15}{|c|}{ Abnormal Returns for Companies whose Ranks have Fallen } \\
\hline 31 & -1.08 & -1.67 & 0.16 & -0.43 & -1.49 & -0.87 & 0.42 & -0.63 & -0.58 & 0.74 & -0.17 & -2.00 & -7.60 & 0.84 \\
\hline \multicolumn{15}{|c|}{ Average Abnormal Return for Companies that Fell Out of the Top 100} \\
\hline 36 & -1.21 & -1.49 & -1.47 & -1.25 & 0.90 & 2.64 & -0.67 & -1.95 & -1.08 & 0.56 & -0.24 & -0.12 & -5.39 & 1.30 \\
\hline \multicolumn{15}{|c|}{ Average Abnormal Return for Companies that Went Into the Top 100} \\
\hline 36 & 0.22 & 0.06 & 1.95 & 0.39 & 0.18 & -0.31 & -0.81 & 0.23 & 1.29 & 0.01 & -0.48 & 1.11 & 3.82 & 0.78 \\
\hline \multicolumn{15}{|c|}{ Average Abnormal Return for Non-S\&P 500 Companies with Scores } \\
\hline 31 & 0.12 & 0.83 & 2.19 & 1.43 & 1.45 & -0.89 & -0.95 & 1.41 & 0.06 & -0.26 & 0.74 & 1.11 & 7.25 & 0.99 \\
\hline
\end{tabular}


Table 4: Cumulative Abnormal Returns for Various Portfolios

\begin{tabular}{|c|c|c|c|c|c|c|}
\hline Companies & 2000 & 2001 & 2002 & 2003 & 2004 & Average \\
\hline \multicolumn{7}{|c|}{ Panel A: Abnormal Returns Relative to Company Characteristics } \\
\hline In Top 100 & -8.56 & -8.71 & 4.98 & 6.22 & -5.16 & -2.25 \\
\hline With Ranks Rising & - & -7.90 & -7.92 & -1.86 & -1.91 & -4.89 \\
\hline With Ranks Falling & - & -1.00 & 3.42 & -0.52 & 7.95 & 2.46 \\
\hline Dropping out of Top 100 & - & -0.93 & -14.79 & 19.97 & -6.15 & -0.47 \\
\hline Entering Top 100 & - & 1.32 & 1.03 & 55.84 & -8.46 & 12.44 \\
\hline In Top 100 but not in S\&P 500 & 19.40 & 19.77 & -10.18 & -38.79 & -18.20 & -5.92 \\
\hline \multicolumn{7}{|c|}{ Panel B: Abnormal Returns Relative to Industrial Classification } \\
\hline In Top 100 & -9.66 & -11.00 & 3.23 & -3.02 & 0.29 & -4.04 \\
\hline With Ranks Rising & - & -15.80 & 5.29 & -2.48 & -3.85 & -3.73 \\
\hline With Ranks Falling & - & -13.34 & -7.94 & -16.38 & 4.68 & -5.56 \\
\hline Dropping out of Top 100 & - & -11.51 & -10.99 & 2.47 & -4.62 & -4.10 \\
\hline Entering Top 100 & - & -1.05 & 7.50 & 7.44 & 1.07 & 3.29 \\
\hline In Top 100 but not in S\&P 500 & 15.91 & 3.97 & 1.74 & 4.50 & 4.50 & 5.80 \\
\hline
\end{tabular}

Note: The expected returns given firm characteristics are calculated using the fitted values from the regression of stock returns on CAP, PTBV, and the previous year's return for non-Top 100 S\&P 1500 stocks, each multiplied by the average value of the characteristics for firms included in the portfolio under study. Expected returns given industrial classification are generated in a similar fashion, based on a regression of the stock returns on dummy variables for each industry. Returns are for the sum of monthly returns from the month after the announcement in each year (usually April). Abnormal returns are defined as actual returns minus returns expected given company characteristics (Panel A) or industry classification (Panel B).

Table 5: Regressions on Firm Characteristics for Various Portfolios $r_{t}=\alpha_{1}+u_{t}$ $r_{t}=\beta_{1}+\beta_{2} R M R F_{t}+\beta_{3} S M B_{t}+\beta_{4} H M L_{t}+\beta_{5} M O M_{t}+u_{t}$

\begin{tabular}{cccccccc}
\multicolumn{7}{c}{$r_{t}=\beta_{1}+\beta_{2} R M R F_{t}+\beta_{3} S M B_{t}+\beta_{4} H M L_{t}+\beta_{5} M O M_{t}+u_{t}$} \\
\hline 1. In Top 100 & $\alpha_{1}$ & $\beta_{1}$ & $\beta_{2}$ & $\beta_{3}$ & $\beta_{4}$ & $\beta_{5}$ & $\mathrm{R}^{2}$ \\
\hline \multirow{4}{*}{ 2. With Ranks Falling } & -0.278 & -0.09 & -0.10 & -0.041 & -0.118 & -0.012 & 0.11 \\
& $(0.176)$ & $(0.195)$ & $(0.049)^{* *}$ & $(0.058)$ & $(0.055)^{* *}$ & $(0.029)$ & \\
& -0.634 & -0.592 & 0.007 & -0.140 & 0.089 & -0.018 & 0.06 \\
3. With Ranks Rising & -0.374 & -0.106 & -0.179 & -0.055 & -0.218 & 0.056 & 0.31 \\
& $(0.265)$ & $(0.249)$ & $(0.081)^{* *}$ & $(0.082)$ & $(0.109)^{*}$ & $(0.071)$ & \\
4. Dropping out of & -0.449 & -0.438 & 0.148 & -0.130 & -0.038 & 0.155 & 0.07 \\
Top 100 & $(0.345)$ & $(0.375)$ & $(0.122)$ & $(0.124)$ & $(0.164)$ & $(0.106)$ & \\
5. Entering Top 100 & 0.319 & 0.443 & -0.116 & -0.025 & -0.048 & -0.107 & 0.08 \\
& $(0.234)$ & $(0.254)^{*}$ & $(0.082)$ & $(0.084)$ & $(0.111)$ & $(0.072)$ & \\
6. In Top 100 but not & 0.605 & 0.198 & -0.110 & 0.139 & 0.223 & 0.049 & 0.30 \\
in S\&P 500 & $(0.309)^{* *}$ & $(0.519)$ & $(0.076)$ & $(0.090)$ & $(0.086)^{* *}$ & $(0.045)$ & \\
\hline
\end{tabular}

Notes: The dependent variable in these regressions is the excess return over the S\&P 500 in that month. Cell entries refer to regression parameters with standard errors in parentheses; $*$ and $* *$ denote significance at the $10 \%$ and $5 \%$ levels, respectively; $R^{2}$ is for the 4-factor regression; $T=60$ monthly observations for portfolios $1 \& 6$, and $T=48$ for portfolios $2-5$. 